\title{
HUBUNGAN LAMA KONTAK, JENIS PEKERJAAN DAN PENGGUNAAN APD DENGAN KEJADIAN DERMATITIS KONTAK PADA PEKERJA TAHU, KEDIRI
}

\author{
RELATIONSHIP OF LONG CONTACT, TYPE OF WORK AND USE OF APD WITH \\ DERMATITIS CASES OF CONTACTS ON TOFU WORKERS, KEDIRI
}

\author{
Mochammad Chafidz, Endang Dwiyanti \\ Departemen Keselamatan dan Kesehatan Kerja \\ Fakultas Kesehatan Masyarakat Universitas Airlangga \\ E-mail: mochafidz900@gmail.com
}

\begin{abstract}
Occupational contact dermatitis is a skin disease which is often arise on industrial no exception of industry on home tofu's factory that can reduce workers productivity. The exposure of chemicals used in the process of clotting can caused contact dermatitis, may lead to irritation and other skin disorders like itching, dry skin and chapped, redness, and sores that do not heal. This was a cross sectional study with quantitative approach. The research was conducted in Maret-Desember 2016 on tofu maker workers in RT 06 RW 02 Joho Village Wates sub-district the district of Kediri. This study used total population of more than 25 people. The Factors suspected as the cause of contact dermatitis is a prolonged contact, type of work and using PPE (Personal Protective Equipment)). The data was collected using a doctor's examination and questionnaires. The correlation between variables was analyzed analytically by using Chi-Square Technique. The result showed that $72 \%$ respondent complain of dermatosis. The analysis result show that prolonged contact $(p=0.007)$, the type of work $(p=0.012)$ and using PPE $(p=0.000)$ had correlation with contact dermatitis. Some things that can be recommended to reduce the risk of contact dermatitis is to raise awareness of workers against skin disease dermatitis contact, wear personal protective equipment such as latex gloves obgyn covering up the sleeves, work clothes covering the entire body and boots.
\end{abstract}

Keywords: dermatitis contact, PPE, prolonged contact

\begin{abstract}
ABSTRAK
Dermatitis kontak akibat kerja yang merupakan salah satu penyakit kelainan kulit sering timbul pada industri tidak terkecuali industri pada pabrik tahu rumahan yang dapat menurunkan produktivitas pekerja. Pemaparan zat kimia yang digunakan dalam proses penggumpalan dapat menyebabkan dermatitis kontak, mengakibatkan iritasi dan gangguan kulit lainnya dalam bentuk gatal-gatal, kulit kering dan pecah-pecah, kemerah-merahan, serta koreng yang tidak sembuhsembuh. Penelitian ini dilaksanakan dengan rancangan cross sectional dengan menggunakan pendekatan kuantitatif. Penelitian ini dilakukan pada bulan Maret-Desember 2016 pada pekerja pembuat tahu yang berada di wilayah RT 06 RW 02 Desa Joho Kecamatan Wates Kabupaten Kediri. Penelitian ini menggunakan total populasi sebanyak 25 orang. Faktor yang diduga sebagai penyebab dermatitis kontak adalah lama kontak, jenis pekerjaan dan penggunaan APD. Pengumpulan data menggunakan lembar pemeriksaan dokter dan kuesioner. Data yang diperoleh kemudian di uji menggunakan uji chi-square dengan tingkat kemaknaan $\alpha=0,05$. Hasil penelitian menunjukkan bahwa sebanyak $72 \%$ responden mengalami dermatitis kontak. Hasil penelitian menunjukkan bahwa lama kontak $(p=0,007)$, jenis pekerjaan $(p=0,012)$ dan penggunaan APD $(\mathrm{p}=0,000)$ ada hubungan dengan kejadian dermatosis. Beberapa hal yang dapat disarankan untuk menurunkan risiko terkena dermatitis kontak adalah meningkatkan kesadaran pekerja terhadap penyakit kulit khususnya dermatitis kontak, memakai alat pelindung diri berupa sarung tangan latex obgyn yang menutupi sampai bagian lengan, baju kerja yang menutupi seluruh bagian tubuh dan sepatu boots.
\end{abstract}

Kata kunci: dermatitis, APD, lama kontak

\section{PENDAHULUAN}

Sektor utama dalam perekonomian bangsa Indonesia adalah sektor pertanian. Hampir semua sektor yang ada di Indonesia tidak lepas dari sektor pertanian. Akan tetapi pada kenyataannya, sifat produk pertanian adalah mudah busuk dan rusak, sehingga memerlukan penanganan yang cepat dan cermat. Seiring dengan hal tersebut, peran 
agroindustri menjadi sangat penting, khususnya dalam penanganan terhadap hasil pertanian.

Salah satu hasil pertanian yang banyak digunakan sebagai bahan dasar pembuatan produk pada sektor agroindustri adalah kedelai. Olahan dari kedelai sangat beragam, salah satunya menjadi produk tahu. Jumlah industri tahu di Indonesia mencapai 84.000 unit usaha dengan kapasitas produksi lebih dari 2,56 juta ton per tahun. Sebanyak 80 persen industri tahu berada di Pulau Jawa. Salah satu kota yang dikenal sebagai kota tahu adalah Kota Kediri. Berbagai variasi produk tahu ditawarkan oleh banyak perusahaan tahu di Kota Kediri, meliputi tahu kuning (tahu takwa), tahu putih, serta stik tahu.

Tahu adalah salah satu hasil olahan dari kacang kedelai dimana merupakan sumber protein nabati yang sangat baik. Pengolahannya ini melalui proses pengendapan dan penggumpalan oleh bahan penggumpal. Zat penggumpal yang dapat digunakan antara lain asam cuka, asam laktat dan batu tahu (Sinta, 2010).

Pemaparan zat-zat kimia yang digunakan dalam proses penggumpalan terhadap tahu dapat mengakibatkan iritasi dan gangguan kulit lainnya dalam bentuk gatal-gatal, kemerah-merahan, kulit kering dan pecah-pecah serta koreng yang tidak cepat sembuh. Kerusakan kulit seperti ini akan memudahkan masuknya zat-zat kimia yang bersifat beracun ke dalam tubuh melalui kulit yang terluka. Uap zat kimia dapat mengakibatkan peradangan dan iritasi saluran pernapasan, dengan gejala batuk, pilek, sesak nafas dan demam. Kebersihan lingkungan kerja di pabrik tahu yang kurang baik (panas, lembab, lantai kotor, basah dan bau yang menyengat) dapat menimbulkan gangguan kesehatan seperti penyakit infeksi, gangguan kenyamanan kerja, kecelakaan, penyakit alergi dan dermatitis kontak (Dinkes Sulsel, 2004).

Menurut Prishandie (2011) sekitar 90\% penyakit kulit akibat kerja pada negara maju merupakan dermatosis kontak, baik itu iritan maupun alergik. Bila dihubungkan dengan jenis pekerjaan, dermatitis kontak dapat terjadi pada semua pekerjaan. Hal ini juga didukung oleh hasil penelitian yang dilakukan Amerika Serikat pada tahun 2002, yang menyebutkan bahwa incident rate penyakit kulit akibat kerja per 10.000 pekerja terbanyak terjadi pada sektor perikanan, pertanian dan kehutanan $(18,8)$ sedangkan pabrik menduduki urutan kedua $(8,4)$ yang kemudian disusul oleh konstruksi $(3,9)$, transportasi $(3,8)$, perdagangan $(3,1)$ dan yang terakhir sektor pertambangan (1,5) (Levy, 2002).

Dermatitis adalah segala kelainan kulit yang timbul pada waktu bekerja atau disebabkan oleh pekerjaan. Salah satu cirinya berupa rasa gatal, penebalan/bintil kemerahan, mengelompok atau tersebar, kadang bersisik, berair dan lainnya akibat permukaan kulit terkena bahan atau unsur-unsur yang ada di lingkungan kerja (Suma 'mur 2009).

Faktor yang paling utama memengaruhi terjadinya dermatitis akibat kerja karena kontak dengan bahan kimia adalah tidak adanya pemakaian APD berupa sarung tangan yang sesuai untuk jenis bahan kimia yang digunakan. Faktor-faktor lain yang memengaruhi dermatitis kontak akibat kerja adalah adanya kontak dengan bahan kimia, lama kontak dan jenis pekerjaan (Lestari dan Utomo, 2008).

Faktor-faktor yang memengaruhi tersebut kerap kali terjadi di sektor informal. Salah satunya terjadi di Sumatera, Puskesmas Medan Deli menunjukkan angka kasus penyakit kulit para pengrajin tahu yaitu 93,42 persen dengan kasus dermatitis kontak dan 6,58 persen dengan kasus penyakit kulit lainnya. Beberapa dari mereka juga menyebutkan bahwa penyakit kulit yang mereka alami diakibatkan oleh karena mereka tidak menggunakan alat pelindung diri seperti sarung tangan pada saat melakukan proses pembuatan tahu (Ernasari, 2012).

Kasus lain terjadi pula di daerah Binjai, beberapa pabrik tahu menyebutkan bahwa $72 \%$ dari pekerja pembuat tahu mengalami reaksi akibat kontak dengan bahan pembuat tahu dalam waktu yang lama. Beberapa dari mereka juga menyebutkan gatal-gatal yang mereka alami tidak akan kunjung sembuh apabila mereka tidak menghentikan pekerjaannya dalam waktu yang lama (Ernasari, 2012).

Berdasarkan identifikasi di atas, maka peneliti tertarik untuk melaksanakan penelitian hubungan lama kontak, jenis pekerjaan dan penggunaan APD dengan kejadian dermatitis kontak pada pekerja pembuat tahu, sehingga diharapkan dengan diadakannya penelitian ini dapat menambah informasi pengelola pabrik tahu dan pekerja pembuat tahu mengenai penyakit akibat kerja khususnya dermatitis kontak.

Kondisi pekerja pada industri informal sangat buruk bila dibandingkan dengan pekerja di industri formal karena kurangnya perhatian dari pihak perusahaan informal terhadap keselamatan dan kesehatan pekerja. Pada industri informal 
keselamatan dan kesehatan pekerja menjadi tanggung jawab pekerja sendiri. Berdasarkan kondisi tersebut dapat dipastikan kemungkinan besar para pekerja informal dapat mengalami kecelakaan dan penyakit akibat kerja.

Kediri terletak di Provinsi Jawa Timur yang mendapat julukan kota tahu. Mendapat julukan kota tahu karena di kota ini terdapat banyak perajin tahu. Penyuplai tahu terbanyak dari Kabupaten Kediri, salah satunya Desa Joho Kec. Wates Kab. Kediri. Wilayah itu terletak di kabupaten pinggiran yang dekat dengan wilayah kota. Berdasarkan hasil observasi yang dilakukan pada tanggal 7 Mei 2016 di RT 06 RW 02 Desa Joho Wates Kab. Kediri dengan 25 orang pekerja, didapatkan 18 pekerja mengalami dermatitis pada kulit (tangan dan kaki) dan 7 pekerja tidak mengalami dermatitis kontak. Hasil tersebut didapat dari pemeriksaan fisik dan diperkuat dengan hasil diagnosa dokter.

Berdasarkan kondisi pada 25 pekerja pembuat tahu tersebut, maka perlu diteliti hubungan lama kontak, jenis pekerjaan dan penggunaan APD dengan kejadian dermatitis kontak pada pekerja pembuat tahu, sehingga diharapkan dengan diadakannya penelitian ini dapat menambah informasi pengelola pabrik tahu dan pekerja pembuat tahu mengenai penyakit akibat kerja khususnya dermatitis kontak.

Rumusan masalah penelitian ini adalah hubungan lama kontak, jenis pekerjaan dan penggunaan APD dengan kejadian dermatitis kontak pada pekerja pembuat tahu home industry pembuatan tahu Kediri.

Tujuan dari penelitian ini adalah menganalisis hubungan lama kontak, jenis pekerjaan dan penggunaan APD dengan kejadian dermatitis kontak pada pekerja pembuat tahu home industry pembuatan tahu Kediri. Tujuan khusus dari penelitian ini adalah menganalisis karakteristik pekerja home industry pembuatan tahu Kediri dan menganalisis hubungan lama kontak, jenis pekerjaan dan penggunaan APD dengan kejadian dermatitis kontak pada pekerja pembuat tahu home industry pembuatan tahu Kediri.

Manfaat penelitian ini bagi responden yaitu mendapatkan informasi tentang hubungan lama kontak, jenis pekerjaan dan penggunaan APD dengan kejadian dermatitis melalui media informasi seperti poster, leaflet dan juga responden yang positif dermatitis akan diberikan penanganan medis lebih lanjut. Kemudian manfaat penelitian bagi instansi terkait yaitu sebagai data penelitian yang dapat dipergunakan sebagai informasi dan dapat dijadikan sebagai masukan bagi pelaksanaan program kesehatan dan keselamatan kerja pada instansi terkait. Selanjutnya manfaat bagi peneliti yaitu sebagai sarana dalam mengaplikasikan pengetahuan yang telah didapatkan pada saat kuliah dan sebagai tambahan pengetahuan serta pengalaman belajar tentang keselamatan dan kesehatan kerja. Dan manfaat bagi peneliti lain yaitu penelitian ini dapat digunakan sebagai informasi ilmiah dan bahan pertimbangan untuk penelitian pada bidang yang sama dalam waktu dan tempat yang berbeda

\section{METODE}

Penelitian ini adalah penelitian dengan menggunakan analitik observasional. Penelitian ini dilakukan untuk mengetahui faktor yang berhubungan dengan risiko kejadian dermatitis kontak pada pekerja pembuat tahu Kediri. Penelitian ini menggunakan desain studi cross sectional dimana data variabel dependen dan independen diamati pada waktu (periode) yang sama.

Populasi penelitian yang menjadi subjek penelitian yang akan diukur adalah seluruh pekerja pembuat tahu home industry yang berjumlah 25 . Penelitian ini menggunakan total populasi pekerja pembuat tahu home industry yang berada di wilayah RT 06 RW 02 Desa Joho Kecamatan Wates Kabupaten Kediri yang berjumlah 25 orang.

Penelitian ini dimulai dari pembuatan proposal pada Maret 2016 hingga penulisan laporan hasil penelitian pada bulan Desember 2016 pada home industry tahu Kediri.

Teknik dan instrumen pengumpulan data dengan menggunakan lembar pemeriksaan dokter dan kuesioner. Diagnosa dermatitis kontak ditegakkan berdasarkan gejala klinis dan anamnesis yang dilakukan oleh dokter, dengan hasil ukur dermatitis kontak atau tidak dermatitis kontak. Hasilnya akan dicatat dalam lembar pemeriksaan dokter. Menurut Mutoif, (2008). Kuesioner yang dibacakan merupakan kuesioner yang dibacakan pertanyaannya sesuai sepahaman responden dan sudah disediakan jawabannya sehingga responden cukup mendengar kemudian menjawab pertanyaan yang diajukan dari peneliti. Kuesioner tertutup digunakan dengan alasan agar lebih sistematis sehingga memudahkan responden dalam menjawab pertanyaan, selain itu keterbatasan waktu penelitian dan keterbatasan biaya menjadi alasan digunakannya kuesioner tertutup. 
Variabel yang dapat diketahui dari kuesioner tertutup yaitu lama kontak, jenis pekerjaan dan penggunaan APD.

Data primer yaitu data yang diperoleh secara langsung oleh peneliti dari pekerja pembuat tahu di wilayah Desa Joho Kecamatan Wates Kabupaten Kediri. Dimana sebelumnya peneliti menjelaskan tujuan penelitian sampai responden memahami dan menyetujui untuk membantu penelitian dan bersedia untuk menandatangani "Informed consent". Data primer yang akan diteliti dapat diperoleh dari kuesioner yaitu lama kontak, jenis pekerjaan dan penggunaan APD.

Seluruh data yang terkumpul akan diolah melalui tahap-tahap pengolahan data. Pengolahan data terdiri dari serangkaian tahapan yang harus dilakukan agar data siap untuk diuji statistik dan dilakukan analisis atau interpretasi. Pengolahan data dilakukan dengan melakukan data coding, data editing, data structure, data entry, dan data cleaning.

Data coding adalah kegiatan mengklasifikasikan data dan memberi kode untuk masing-masing kelas sesuai dengan tujuan dikumpulkannya data. Data editing adalah penyuntingan sebelum proses pemasukan data. Sebelum diolah, data diteliti apabila ada kesalahan dan dibetulkan apabila masih ada kesalahan serta memeriksa kelengkapannya. Data structure dikembangkan sesuai dengan analisis yang akan dilakukan dan jenis perangkat lunak yang dipergunakan. Pada saat menggunakan data structure, bagi masing-masing variabel perlu ditetapkan nama, skala ukur variabel, jumlah digit. Data entry Merupakan proses pemasukan data ke dalam program atau fasilitas analisis data di dalam komputer. Data cleaning merupakan proses pembersihan data setelah data di entri. Cara yang sering dilakukan adalah dengan melihat distribusi frekuensi dari variabel-variabel dan menilai kelogisannya. Tahapan cleaning data terdiri dari mengetahui missing data, mengetahui variasi data dan mengetahui konsistensi data.

Teknik analisis data penelitian ini dilakukan untuk melihat distribusi frekuensi dan presentase dari variabel dependen dan variabel independen antara faktor lama kontak, jenis pekerjaan dan pemakaian APD. Analisis bivariat adalah analisis yang dilakukan untuk mengetahui ada atau tidaknya hubungan antara variabel independen yaitu lama kontak, jenis pekerjaan dan pemakaian APD terhadap faktor dependen yaitu kejadian dermatitis kontak. Analisa bivariat menggunakan uji chi- square untuk variabel kategori dan untuk variabel numerik menggunakan uji Mann-Withney karena data yang diperoleh tidak berdistribusi normal. Derajat kepercayaan yang digunakan adalah $95 \%$. Jika $\mathrm{P}$ value $<0,05$ maka perhitungan secara statistik menunjukkan bahwa adanya hubungan bermakna antara variabel independen dan variabel dependen.

\section{HASIL}

Home industry Tahu Kediri yang dibuat penelitian ini terletak di wilayah RT 06 RW 02 Desa Joho Kecamatan Wates Kabupaten Kediri. Di wilayah ini terdapat 8 (delapan) pemroduksi tahu rumahan yang sudah lama ada sejak tahun 1980an. Bisnis ini diturunkan dari orang tua mereka dahulu, kemudian menyebar di sekitaran Kota/Kabupaten Kediri.

Bisnis tahu home industry ini mempunyai ruang produksi yang bervariasi mulai berukuran $30 \mathrm{~m}^{2}$ sampai $120 \mathrm{~m}^{2}$. Jumlah pekerja juga bervariasi mulai dari 2 (dua) orang sampai 6 (enam) orang per rumah produksi. Pekerja pembuat tahu di RT 06 RW 02 Desa Joho Kecamatan Wates Kabupaten Kediri ini berjumlah 25 orang, dengan 13 (tiga belas) orang berjenis kelamin perempuan dan 12 (dua belas) orang berjenis kelamin laki-laki.

Hasil produksi tahu dipasarkan di sekitaran Desa Joho dan paling jauh adalah dikirim ke Kota Kediri. Macam produksinya kebanyakan adalah tahu, tapi ada 2 (dua) tempat yang juga memproduksi susu kedelai. Berdasarkan wawancara terhadap salah satu pemilik pabrik, setiap $10 \mathrm{~kg}$ kacang kedelai dapat menghasilkan 400 buah tahu putih. Semua pemilik pabrik tahu mengaku tidak menambahkan bahanbahan berbahaya seperti formalin ke dalam tahu mereka. Bahan penyedap yang digunakan hanya garam dan kunyit (untuk tahu kuning).

Para pekerja di pabrik tahu umumnya tidak mengetahui bahwa larutan penggumpal yang digunakan untuk mengendapkan protein kedelai adalah termasuk zat kimia. Larutan penggumpal ini hanya mereka sebut dengan asam cuka yang terbuat dari air kelapa muda. Larutan penggumpal ini tidak setiap hari dibuat. Asam cuka ini digunakan sebagai bibit pertama larutan penggumpalan. Jika larutan penggumpalan yang terbuat dari asam cuka tersebut selesai digunakan maka akan disimpan dan digunakan kembali pada pemasakan berikutnya.

Larutan sisa penggumpalan yang dipakai lagi keesokan harinya disebut dengan air cuka. Air cuka adalah cairan sisa proses penggumpalan dalam 
pembuatan tahu yang masih dapat digunakan lagi sebagai bahan penggumpalan selanjutnya. Agar dapat digunakan lagi untuk menggumpalkan protein dalam pembuatan tahu, sisa cairan air cuka harus disimpan selama 1 x 24 jam untuk memberikan kesempatan kepada bakteri asam cuka untuk memfermentasikannya. Air cuka tidak mempunyai batas kedaluwarsa.

Dari hasil pengujian $\mathrm{pH}$ dari cairan penggumpal atau air cuka didapatkan kisaran $\mathrm{pH}$ air cuka yang digunakan oleh para pekerja pembuat tahu sebesar 3-4. Artinya zat penggumpal ini memang bersifat asam. Tingkat keasaman suatu bahan kimia akan meningkat seiring dengan semakin rendahnya $\mathrm{pH}$ bahan kimia tersebut. Semakin asam larutan maka makin kecil nilai $\mathrm{pH}$, dan sebaliknya. Bila $\mathrm{pH}$ berkurang, konsentrasi ion hidronium akan meningkat, dan konsentrasi ion hidroksida berkurang. Bahan kimia yang mempunyai $\mathrm{pH}$ kurang dari 7 bersifat asam.

Bagian pekerjaan pada pabrik tahu di wilayah Desa Joho terdiri dari bagian memasak, bagian penjualan dan mengerjakan semua bagian. Bagian memasak mengerjakan semua diproses memasak yaitu penggilingan, perendaman, pencucian, penyaringan, perebusan, pengendapan, penambahan larutan penggumpal, pencetakan, pengepresan dan pemotongan.

Tabel 1. Gambaran Tahapan Proses Kerja pada Home industry Tahu beserta Jenis Pekerjaan

\begin{tabular}{|c|c|c|}
\hline No & Tahapan & $\begin{array}{l}\text { Bagian } \\
\text { Kerja }\end{array}$ \\
\hline 1 & Perendaman kedelai & \multirow{3}{*}{ Penggilingan } \\
\hline 2 & Pencucian kedelai & \\
\hline 3 & Penggilingan & \\
\hline 4 & Perebusan & \multirow[b]{3}{*}{ Penyaringan } \\
\hline 5 & Penyaringan & \\
\hline 6 & $\begin{array}{l}\text { Pengendapan dan penambahan } \\
\text { larutan penggumpal (setelah } \\
\text { disaring maka bubur tahu } \\
\text { diendapkan pada larutan } \\
\text { penggumpal) }\end{array}$ & \\
\hline 7 & Pencetakan dan pengepresan & \multirow{3}{*}{ Pencetakan } \\
\hline 8 & Pemotongan tahu & \\
\hline 9 & Pengepakan & \\
\hline 10 & Penjualan & Penjualan \\
\hline
\end{tabular}

Tabel 2. Kejadian Dermatitis Kontak pada Tangan Pekerja Pembuat Tahu di Wates Kab.Kediri 2016

\begin{tabular}{llcc}
\hline No & Kejadian Dermatitis Kontak & N & $\begin{array}{c}\text { Persentase } \\
(\mathbf{\%})\end{array}$ \\
\hline 1 & $\begin{array}{l}\text { Mengalami Dermatitis } \\
\text { Kontak }\end{array}$ & 18 & 72 \\
\hline 2 & $\begin{array}{l}\text { Tidak Mengalami Dermatitis } \\
\text { Kontak }\end{array}$ & 7 & 28 \\
\hline Total & 25 & 100 \\
\hline
\end{tabular}

Bagian penjualan bertugas menjual hasil produksi tahu sedangkan semua bagian bertugas lebih ke penjualan namun ikut serta dalam proses pemasakan. Delapan home industry pembuatan tahu yang berada di RT 06 RW 02 Desa Joho, pembagian kerjanya tidaklah jelas, tapi kebanyakan perempuan bertanggung jawab proses pemasakan, sedangkan laki-laki lebih ke penjualan.

Hasil penelitian mengenai gambaran kejadian dermatitis kontak pada pekerja pembuat tahu di RT 06 RW 02 Desa Joho Kabupaten Kediri tahun 2016 dapat dilihat pada Tabel 2 dan Tabel 3. Kejadian dermatitis kontak dalam penelitian ini dibagi menjadi dua bagian yaitu kejadian dermatitis kontak pada tangan pekerja dan kaki pekerja. Indikator kejadian dermatitis kontak secara umum menggunakan hasil kejadian dermatitis kontak pada tangan, karena tangan lebih mewakili organ tubuh yang sangat berperan dalam pengerjaan pembuatan tahu. Kejadian dermatitis kontak pada kaki digunakan untuk menghubungkan pemakaian APD (Alat Pelindung Diri). Hal ini dikarenakan pada home industry tahu di wilayah RT 06 RW 02 Desa Joho Kabupaten Kediri pemakaian APD yang digunakan hanyalah sepatu boots, sedangkan pemakaian APD pada tangan tidak ada. Jadi dalam penelitian ini

Tabel 3. Kejadian Dermatitis Kontak pada Kaki Pekerja Pembuat Tahu di Wates Kab. Kediri 2016

\begin{tabular}{clcc}
\hline No & Kejadian dermatitis & N & $\begin{array}{c}\text { Persentase } \\
(\mathbf{\%})\end{array}$ \\
\hline 1 & $\begin{array}{l}\text { Mengalami dermatitis } \\
\text { kontak }\end{array}$ & 7 & 28 \\
\hline 2 & $\begin{array}{l}\text { Tidak mengalami } \\
\text { dermatitis kontak }\end{array}$ & 18 & 72 \\
\hline Total & 25 & 100 \\
\hline
\end{tabular}


Tabel 4. Distribusi Frekuensi Responden Berdasarkan Lama Kontak pada Pekerja Home industry Tahu Kediri.

\begin{tabular}{|c|c|c|c|c|}
\hline $\begin{array}{c}\text { Lama } \\
\text { Kontak }\end{array}$ & $\begin{array}{l}\text { Frekuensi } \\
\text { (n) }\end{array}$ & $\begin{array}{c}\text { Persentase } \\
(\%)\end{array}$ & $\begin{array}{l}\text { Rata- } \\
\text { Rata }\end{array}$ & Range \\
\hline$<5$ Jam & 10 & 40 & \multirow{3}{*}{$\begin{array}{l}4,68 \\
\text { Jam }\end{array}$} & \multirow{3}{*}{$\begin{array}{c}0 \text { jam/ } \\
\text { hari-9 } \\
\text { jam/har }\end{array}$} \\
\hline$\leq 5 \mathrm{Jam}$ & 15 & 60 & & \\
\hline Total & 25 & 100 & & \\
\hline
\end{tabular}

supaya lebih valid, hasil dermatitis kontak pada kaki pekerja hanya digunakan dalam menghubungkan variabel pemakaian APD.

Dari data yang tercantum dalam Tabel 2 dapat dilihat bahwa sebagian besar $72 \%$ pekerja tahu mengalami dermatitis kontak pada tangannya.

Dari data yang tercantum dalam Tabel 3 dapat dilihat bahwa sebagian besar $72 \%$ pekerja tahu tidak mengalami dermatitis kontak pada kakinya.

Faktor yang memengaruhi terjadinya dermatitis kontak terdiri dari faktor eksternal (lama kontak, frekuensi kontak, suhu dan kelembapan) dan faktor internal (usia, riwayat penyakit kulit, riwayat atopi, riwayat alergi, masa kerja, jenis pekerjaan dan penggunaan APD (sepatu boots).

Responden yang bekerja di home industry tahu Kediri memiliki lama kontak yang berkisar antara $0 \mathrm{jam} / \mathrm{hari}$ sampai dengan $9 \mathrm{jam} / \mathrm{hari}$. Distribusi frekuensi responden berdasarkan lama kontak pekerja dapat dilihat pada Tabel 4.

Data lama kontak diperoleh dari jawaban pertanyaan yang diajukan ke responden oleh peneliti

Tabel 5. Distribusi Frekuensi Responden Berdasarkan Jenis Pekerjaan Pekerja pada Home industry Tahu Kediri.

\begin{tabular}{lcc}
\hline Jenis Pekerjaan & Frekuensi (n) & Persentase (\%) \\
\hline Memasak & 12 & 48 \\
Penjualan & 3 & 12 \\
Semua Bagian & 10 & 40 \\
\hline Total & 25 & 100 \\
\hline
\end{tabular}

Tabel 6. Distribusi Frekuensi Responden Berdasarkan penggunaan APD (Sepatu Boots) Pekerja pada Home industry Tahu Kediri.

\begin{tabular}{lcc}
\hline \multicolumn{1}{c}{ Penggunaan APD } & $\begin{array}{c}\text { Frekuensi } \\
(\mathbf{n})\end{array}$ & $\begin{array}{c}\text { Persentase } \\
(\mathbf{\%})\end{array}$ \\
\hline Memakai & 18 & 72 \\
$\begin{array}{l}\text { Jarang atau Tidak } \\
\text { Memakai }\end{array}$ & 7 & 28 \\
\hline Total & 25 & 100 \\
\hline
\end{tabular}

(pembacaan kuesioner oleh peneliti) berdasarkan jangka waktu paparan bahan penggumpal yang dipakai dalam membuat tahu yang dihitung dalam satu hari kerja. Pada Tabel 4 dapat dilihat bahwa sebanyak $60 \%$ pekerja di home industry Tahu lama kontaknya $\leq 5 \mathrm{Jam}$, rata-rata lama kontak adalah 4,68 jam/hari (4 jam 41 menit/hari) kemudian lama kontak minimum 0 jam/hari dan maksimum 9 jam/ hari.

Data jenis pekerjaan diperoleh dari jawaban pertanyaan yang diajukan ke responden oleh peneliti (pembacaan kuesioner oleh peneliti). Distribusinya dapat dilihat pada Tabel 5. Responden yang bekerja pada semua bagian sebanyak $40 \%$, bagian memasak sebanyak $48 \%$ dan bagian penjualan sebanyak $12 \%$.

Data penggunaan APD berupa sepatu boots diperoleh dari observasi serta wawancara kepada responden oleh peneliti. Distribusinya dapat dilihat pada Tabel 6 responden yang memakai APD berupa sepatu boots berjumlah $72 \%$.

Berdasarkan Tabel 7, diperoleh data bahwa responden yang mengalami dermatitis dan bekerja dengan lama kontak kurang dari 5 jam/hari sebanyak $40 \%$ dan responden yang mengalami dermatitis tetapi bekerja dengan lama kontak lebih dari sama dengan $5 \mathrm{jam} /$ hari sebanyak $93,3 \%$. Sedangkan responden yang bekerja dengan lama kontak kurang dari 5 jam/hari namun tidak mengalami dermatitis kontak sebanyak $60 \%$ dan responden yang bekerja dengan lama kontak lebih dari sama dengan 5

Tabel 7. Hubungan antara Lama Kontak dengan dermatitis kontak pekerja home industry Tahu Kediri

\begin{tabular}{|c|c|c|c|c|c|c|c|c|}
\hline \multirow{3}{*}{ Variabel } & \multirow{3}{*}{ Kategori } & \multicolumn{6}{|c|}{ Frekuensi } & \multirow{3}{*}{ P-Value } \\
\hline & & \multicolumn{2}{|c|}{ Dermatitis } & \multicolumn{2}{|c|}{ Tidak Dermatitis } & \multicolumn{2}{|c|}{ Total } & \\
\hline & & n & $\%$ & n & $\%$ & $\mathbf{N}$ & $\%$ & \\
\hline \multirow{2}{*}{ Lama Kontak } & $<5 \mathrm{Jam} /$ Hari & 4 & 40 & 6 & 60 & 10 & 100 & \multirow{2}{*}{0,007} \\
\hline & $\geq 5 \mathrm{Jam} / \mathrm{Hari}$ & 14 & 93 & 1 & 6,7 & 15 & 100 & \\
\hline
\end{tabular}


$\mathrm{jam} /$ hari dan tidak mengalami dermatitis kontak adalah sebanyak 6,7\%. Dari hasil uji statistik dapat diketahui antara lama kontak dan dermatitis kontak didapatkan nilai $p$-value yang dihasilkan adalah sebesar 0,007 , artinya pada $\alpha 5 \%$ terdapat hubungan yang bermakna antara lama kontak dengan dermatitis kontak.

Berdasarkan Tabel 8, diperoleh bahwa responden yang mengalami dermatitis dan mempunyai jenis pekerjaan memasak sebanyak $55,6 \%$, tidak ada responden yang mengalami dermatitis dan mempunyai jenis pekerjaan penjualan $0 \%$, sedangkan responden yang mengalami dermatitis dan mengerjakan di semua bagian sebanyak 44\%. Kemudian responden yang tidak mengalami dermatitis dan pekerjaanya memasak sebanyak $28,6 \%$, responden yang tidak mengalami dermatitis dan pekerjaannya di penjualan sebanyak $42 \%$, sedangkan responden yang tidak mengalami dermatitis dan pekerjaannya di semua bagian sebanyak 28,6\%. Dari hasil uji statistik didapatkan nilai $p$-value sebesar 0,012 . Maka dapat disimpulkan bahwa pada $\alpha 5 \%$ terdapat hubungan yang bermakna antara jenis pekerjaan dengan dermatitis kontak pada pekerja pembuat tahu.

Berdasarkan Tabel 9, diperoleh bahwa tidak ada responden yang memakai APD sepatu boots mengalami dermatitis kontak pada kakinya, kemudian responden yang memakai APD sepatu boots dan tidak mengalami dermatitis pada kakinya sebanyak $100 \%$. Sedangkan responden yang tidak memakai atau jarang menggunakan APD sepatu boots dan mengalami dermatitis pada kakinya sebanyak $100 \%$, kemudian tidak ada responden yang tidak memakai atau jarang menggunakan APD sepatu boots tapi tidak mengalami dermatitis pada kakinya. Dari hasil uji statistik didapatkan nilai p-value sebesar 0.000. Maka dapat disimpulkan bahwa pada $\alpha 5 \%$ terdapat hubungan yang bermakna antara penggunaan APD dengan dermatitis kontak pada kaki pekerja pembuat tahu.

\section{PEMBAHASAN}

Salah satu penyakit yang rentan terjadi pada sektor informal adalah dermatosis. Dermatosis adalah suatu penyakit yang menyerang organ kulit dimana kulit mengalami inflamasi. Dermatosis juga bisa timbul akibat suatu pekerjaan terutama pekerjaan yang berhubungan dengan bahanbahan yang bisa menimbulkan iritan dan alergi. Secara umum dermatosis dibagi menjadi dua: dermatosis kontak iritan dan dermatosis kontak alergi. Dermatosis kontak iritan sebagian besar disebabkan oleh pemaparan iritan berupa bahan kimia dan pelarut. Inflamasi dapat terjadi setelah satu kali pemaparan ataupun setelah pemaparan yang berulang. Dermatosis kontak alergi ditimbulkan oleh senyawa alergen. Senyawa alergen bisa dari bahan kimia maupun berasal dari tanaman (Keefner dan Curry, 2004).

Pada penelitian ini diagnosa dermatitis kontak tidak dilakukan oleh dokter spesialis kulit dan kelamin. Selain itu tidak dilakukan penegakan diagnosa lebih lanjut misalnya dengan melakukan uji temple. Hasil penelitian ini menunjukkan bahwa dari

Tabel 8. Hubungan antara Jenis Pekerjaan dengan Dermatitis Kontak Pekerja Home Industry Tahu Kediri

\begin{tabular}{|c|c|c|c|c|c|c|c|c|}
\hline \multirow{3}{*}{ Variabel } & \multirow{3}{*}{ Kategori } & \multicolumn{6}{|c|}{ Frekuensi } & \multirow{3}{*}{ P-value } \\
\hline & & \multicolumn{2}{|c|}{ Dermatitis } & \multicolumn{2}{|c|}{ Tidak dermatitis } & \multicolumn{2}{|c|}{ Total } & \\
\hline & & $\mathrm{n}$ & $\%$ & n & $\%$ & $\mathbf{N}$ & $\%$ & \\
\hline \multirow{3}{*}{ Jenis Pekerjaan } & Memasak & 10 & 55,6 & 2 & 28,6 & 12 & 48 & \multirow{3}{*}{0,012} \\
\hline & Penjualan & 0 & 0 & 3 & 42,9 & 3 & 12 & \\
\hline & Semua Bagian & 8 & 44,4 & 2 & 28,6 & 10 & 40 & \\
\hline
\end{tabular}

Tabel 9. Hubungan antara Pemakain APD dengan Dermatitis Kontak Pekerja Home Industry Tahu Kediri

\begin{tabular}{|c|c|c|c|c|c|c|c|c|}
\hline \multirow{3}{*}{ Variabel } & \multirow{3}{*}{ Kategori } & \multicolumn{6}{|c|}{ Frekuensi } & \multirow{3}{*}{ P-Value } \\
\hline & & \multicolumn{2}{|c|}{ Dermatitis } & \multicolumn{2}{|c|}{ Tidak Dermatitis } & \multicolumn{2}{|c|}{ Total } & \\
\hline & & n & $\%$ & $\mathbf{n}$ & $\%$ & $\mathbf{N}$ & $\%$ & \\
\hline \multirow{2}{*}{$\begin{array}{l}\text { Penggunaan APD } \\
\text { Sepatu Boots }\end{array}$} & Memakai & 0 & 0 & 18 & 100 & 18 & 100 & \multirow{2}{*}{0,000} \\
\hline & Tidak Memakai & 7 & 100 & 0 & 100 & 7 & 100 & \\
\hline
\end{tabular}


25 pekerja pembuat tahu Kediri didapatkan sebanyak $72 \%$ mengalami dermatitis kontak dan sebanyak $28 \%$ tidak mengalami dermatitis kontak. Pekerja pembuat tahu mengaku rasa gatal dan panas akan dirasakan seseorang jika baru pertama kali bekerja, apalagi jika sebelumnya tidak pernah bersentuhan dengan bahan yang mengandung asam. Selain rasa gatal dan panas, pekerja juga merasakan kelainan kulit berupa fissura (kulit pecah-pecah) dan exudat yang berisi cairan bening. Kejadian dermatitis kontak banyak terjadi pada pekerja yang terkena larutan penggumpal yang digunakan saat tahapan penyaringan, dimana pekerja akan mencampurkan air kedelai yang telah direbus dan disaring kelarutan penggumpal yang mengandung asam. Pekerja banyak yang tidak mengetahui bahwa gejala yang mereka rasakan adalah dermatitis kontak, kebanyakan dari mereka tidak rutin melakukan pengobatan karena gejala ringan seperti gatal dan perih dapat hilang jika mereka berhenti bekerja.

Menurut Hudyono (2002), pekerja yang berkontak dengan bahan kimia menyebabkan kerusakan sel kulit lapisan luar, semakin lama berkontak dengan bahan kimia maka akan semakin merusak sel kulit lapisan yang lebih dalam dan memudahkan untuk terjadinya dermatitis. Kontak dengan bahan kimia yang bersifat iritan atau alergen secara terus menerus akan menyebabkan kulit pekerja mengalami kerentanan mulai dari tahap yang ringan sampai tahap yang berat. Lama kontak adalah jangka waktu pekerja berkontak dengan bahan kimia dalam hitungan jam/hari. Setiap pekerja memiliki lama kontak yang berbeda-beda sesuai dengan proses kerjanya. Semakin lama berkontak dengan bahan kimia maka peradangan atau iritasi kulit dapat terjadi sehingga menimbulkan kelainan kulit (Lestari dan Utomo, 2007).

Pada penelitian ini didapatkan bahwa rata-rata lama kontak pekerja pembuat tahu dengan bahan kimia yang digunakan untuk tahap penggumpalan adalah 4,68 jam/hari (4 jam 40 menit/hari). Pekerja ada yang berkontak langsung dengan bahan penggumpal, ada pula yang sama sekali tidak berkontak dengan larutan penggumpal, tergantung jenis pekerjaan mereka. Sehingga lama kontak minimum pada penelitian ini adalah $0 \mathrm{jam} / \mathrm{hari}$ dan lama kontak maksimum yaitu 9 jam/hari.

Penelitian ini sejalan dengan hasil penelitian Lestari dan Utomo (2008) yang menunjukkan bahwa terdapat hubungan yang bermakna antara lama kontak dengan kejadian dermatitis kontak ( $p$-value

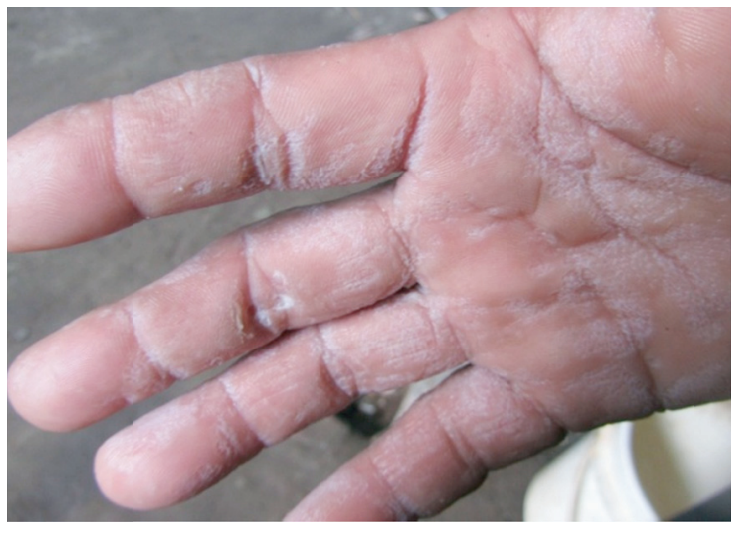

Gambar 1. Dermatitis pada Pekerja Pembuat Tahu Kediri

0,003). Hasil penelitian Lestari dan Utomo (2008) menunjukkan bahwa pekerja yang berkontak lebih lama cenderung lebih banyak menderita dermatitis kontak daripada pekerja dengan jangka waktu paparan lebih singkat.

Seperti dengan hal yang diungkapkan oleh Hudyono (2002) sebelumnya, bahan penggumpal tahu yang mengandung asam dapat menyebabkan kerusakan sel kulit lapisan luar, semakin lama berkontak dengan bahan kimia maka akan semakin merusak sel kulit lapisan yang lebih dalam dan memudahkan untuk terjadinya dermatitis.

Responden yang bekerja pada semua bagian sebanyak $40 \%$, bagian memasak sebanyak $48 \%$ dan bagian penjualan $12 \%$. Berdasarkan hasil analisis bivariat, responden yang mengalami dermatitis pada bagian memasak yaitu sebanyak $55,6 \%$, bagian penjualan tidak ada ( $0 \%$ ) dan semua bagian $44,4 \%$. Hasil penelitian ini terdapat hubungan yang bermakna antara jenis pekerjaan dengan dermatitis kontak pada pekerja pembuat tahu. Meskipun penelitian ini menggunakan desain cross sectional, sehingga lemah dalam menganalisis hubungan sebab akibat.

Hasil penelitian ini sejalan dengan yang dikemukakan oleh Lestari dan Utomo (2007) bahwa terdapat perbedaan jumlah pekerja yang mengalami dermatitis kontak berdasarkan jenis pekerjaannya. Hasil penelitian ini juga sejalan dengan penelitian yang dilakukan oleh Ferdian (2012) dalam penelitian tersebut didapatkan $p$-value sebesar 0,001 dimana artinya terdapat hubungan antara jenis pekerjaan dengan dermatitis kontak pada pembuat tahu di wilayah Ciputat dan Ciputat Timur. 
Proses pekerjaan memasak pada bagian penyaringan memang bersentuhan langsung dengan larutan penggumpal tahu. Proses dimulai dari merebus bubur kedelai hasil penggilingan, mencampurkan hasil rebusan dengan larutan penggumpal dan diakhiri dengan menyaring hasil penggumpalan. Dari tahapan tersebut dapat dikatakan bahwa bagian penyaringan berisiko untuk terkena dermatitis kontak kemungkinan dikarenakan terpapar oleh larutan penggumpal yang bersifat asam dan didukung oleh paparan air yang cukup panas saat mencampurkan larutan penggumpal dengan bubur kedelai hasil rebusan.

Pemakaian mesin pengaduk dan mesin penyaring juga dapat mengurangi keterpaparan bahan penggumpal yang bersifat asam tersebut. Selain itu pekerja diharapkan untuk tetap menggunakan alat pelindung diri berupa sarung tangan yang panjangnya sampai lengan dan sepatu boots agar tangan dan kaki tidak langsung bersentuhan dengan larutan penggumpal dalam proses penyaringan.

Pemakaian sarung tangan bagi beberapa orang menimbulkan masalah seperti perasaan kaku, risih, maupun mengganggu penampilan. Meskipun begitu pada bidang industri, sarung tangan memberikan perlindungan terhadap bahaya yang mungkin terjadi karena pekerjaan tersebut menimbulkan kemungkinan risiko kecelakaan yang berbahaya bagi diri dan anggota badan pekerja tersebut. Sarung tangan dapat melindungi pekerja dari kemungkinan celaka seperti kejutan aliran listrik, terbakar, maupun percikan logam panas.

Berdasarkan hasil yang diperoleh bahwa semua responden yang memakai APD sepatu boots tidak mengalami dermatitis kontak pada kakinya, sedangkan semua responden yang tidak memakai atau jarang menggunakan APD sepatu boots, semua mengalami dermatitis pada kakinya.

Hasil penelitian ini sejalan dengan apa yang dikemukakan oleh Erliana (2008), bahwa terdapat perbedaan proporsi antara pekerja yang menggunakan APD dengan pekerja yang tidak menggunakan APD. Proporsi pekerja yang tidak menggunakan APD diketahui 87,5\% menderita dermatitis kontak dibandingkan dengan pekerja yang menggunakan APD hanya 19,0\%. Hasil uji chi square menunjukkan bahwa variabel penggunaan APD mempunyai hubungan yang signifikan dengan kejadian dermatitis kontak dengan $p$-value 0,001 .

Penelitian Nuraga (2006), juga menyebutkan bahwa besarnya risiko kelompok pekerja yang kadang-kadang menggunakan APD dibandingkan dengan kelompok pekerja yang menggunakan APD terhadap kejadian dermatitis kontak (positif) adalah 8,556 . Artinya pekerja yang kadang-kadang memakai APD mempunyai risiko mengalami dermatitis kontak 8,556 kali lebih besar dari pekerja yang selalu menggunakan APD. Nilai kisaran (minimum dan maksimum) Odds Ratio sebesar 2,018-36,279, berarti bahwa dengan tingkat kepercayaan 95\% kelompok responden yang kadang-kadang menggunakan APD mempunyai risiko yang lebih besar dibandingkan dengan kelompok responden yang selalu menggunakan APD.

Terkait dengan hasil tersebut, maka sebaiknya pemilik pabrik dan pekerja sama-sama paham akan bahaya dermatitis kontak dan sadar akan pentingnya penggunaan APD dalam bekerja. Sebaiknya pekerja menggunakan APD pada badan dengan menggunakan baju serta tambahan celemek, kaki menggunakan sepatu boots, dan tangan menggunakan sarung tangan yang terbuat dari latex (karet) yang biasanya digunakan oleh tenaga medis seperti dokter obgyn, bidan ataupun perawat. Pemilihan menggunakan APD sarung tangan obgyn karena sarung tangan ini memiliki tekstur paling lentur dan sarung tangan ini bisa menutupi dari ujung jari sampai lengan bagian atas. Jadi sangat cocok untuk menghindari tangan dari cairan asam.

\section{SIMPULAN}

Berdasarkan hasil penelitian dan pembahasan yang telah dijelaskan maka dapat ditarik kesimpulan bahwa; Pekerja pembuat tahu yang menderita dermatitis kontak adalah sebanyak $72 \%$. Pada pekerja pembuat tahu rata-rata lama kontak adalah 4,68 jam/hari (1 jam 40 menit/hari) dan sebanyak $60 \%$ pekerja di home industry tahu lama kontaknya $\leq 5 \mathrm{Jam}$. Pada faktor jenis pekerjaan responden yang bekerja pada semua bagian sebanyak $40 \%$, bagian pemasakan sebanyak $48 \%$ dan bagian penjualan $12 \%$. Pada faktor penggunaan APD semua responden yang menggunakan APD sepatu boot tidak mengalami dermatitis kontak pada kakinya, begitu juga sebaliknya semua pekerja yang tidak memakai sepatu boot kakinya mengalami dermatitis kontak. Lama kontak, jenis pekerjaan dan penggunaan APD adalah faktor yang berhubungan dengan kejadian dermatitis kontak. 


\section{DAFTAR PUSTAKA}

Depkes. 2008. Pedoman Tatalaksana Penyakit Akibat Kerja bagi Petugas Kesehatan Jakarta Tahun 2008. Karya Tulis Ilmiah. Direktorat Jenderal Bina Kesehatan Jakarta.

Dinas Kesehatan Sulawesi Utara. Upaya Kesehatan Kerja Bagi Perajin (Kulit, Mebel, Aki Bekas, Tahu \& Tempe, Batik). Available: http://dinkesulsel. go.id/new/images/pdf/pedoman/pedoman $\% 20$ upaya $\% 20$ yankes $\% 20$ perajin.pdf.

Erliana. 2008. Hubungan Karakteristik Individu dan Penggunaan Alat Pelindung Diri dengan Kejadian Dermatitis Kontak pada Pekerja Paving Block CV. F. Lhokseumawe Tahun 2008. Tesis. Universitas Sumatera Utara.

Ernasari. 2012. Pengaruh Penyuluhan Dermatitis Kontak terhadap Pengetahuan dan Sikap Perajin Tahu di Kelurahan Mabar Kecamatan Medan Deli Tahun 2011. Tesis. Universitas Sumatera Utara.

Ferdian, R. 2012. Faktor-Faktor yang Berhubungan dengan Kejadian Dermatitis Kontak pada Pekerja Pembuat Tahu di Wilayah Kecamatan Ciputat dan Ciputat Timur Tahun 2012. Skripsi. Universitas Islam Negeri Syarif Hidayatullah Jakarta.

Hudyono, J. 2002. Dermatitis Akibat Kerja. Jakarta: Majalah kedokteran Indonesia. 2011. Skripsi. Universitas Indonesia Jakarta.

Keefner, D.M., dan Curry, C.E. 2004. Contact Dermatitis dalam Handbook of Nonprescription Drugs, 12th edition, APHA, Whasington D.C.
Lestari, F., Utomo, H.S. 2007. Faktor-Faktor yang Berhubungan dengan Dermatitis Kontak pada Pekerja di PT. Inti Pantja Press Industri. Skripsi. Universitas Indonesia.

Lestari, F., Utomo, H.S. 2008. Faktor-Faktor yang Memengaruhi Kejadian Dermatitis Kontak pada Pekerja yang Terpajan dengan Bahan Kimia di Perusahaan Industri Otomotif Kawasan Industri Cibitung Jawa Barat. Jurnal Makara Kesehatan, 12(2): pp. 63-70.

Levy. 2002. Occupational Disease. Jurnal. Universitas Islam Negeri Syarif Hidayatullah Jakarta.

Mutoif, D. 2008. Pengenalan Alat-Alat Laboratorium Terapan dan Rekayasa Hygiene Perusahaan dan Keselamatan Kerja (Hyperkes). Karya Tulis Ilmiah. Politeknik Kesehatan Yogyakarta.

Nuraga, W. 2006. Faktor-Faktor yang Memengaruhi Kejadian Dermatitis Kontak pada Pekerja yang Terpajan dengan Bahan Kimia di PT. Moric Indonesia Tahun 2006. Tesis. Universitas Indonesia.

Prisandhie, A. 2011. Faktor yang berhubungan dengan Keluhan Dermatosis pada Pekerja Pencuci Sepeda Motor dan Mobil di Sepanjang Jalan Mulyorejo Tahun 2011. Skripsi. Universitas Airlangga Surabaya.

Sinta, D.A. 2010. Pengaruh Lama Perendaman Kedelai dan Jenis Zat Penggumpal terhadap Mutu Tahu Tahun 2010. Skripsi. Universitas Diponegoro Semarang.

Suma'mur, P.K. 2009. Higiene Perusahaan dan Kesehatan Kerja. Jakarta: Sagung Seto. 